\title{
Detection of some soil properties using hyperspectral remote sensing of semi arid region of Tamil Nadu
}

RAJESHWAR MALAVATH AND S. MANI

Received : 21.02.2017; Revised : 14.05.2017; Accepted : 24.05.2017

MEMBERS OF RESEARCH FORUM:

Corresponding author : RAJESHWAR MALAVATH, Department of Soil Science and Agricultural Chemistry, College of Agriculture, Prof. Jayashankar Telangana State Agricultural University, Rajendranagar, HYDERABAD (TELANGANA) INDIA Email: rajeshoct31naik@gmail.com

Co-authors :

S. MANI, Department of Soil Science and Agricultural Chemistry, Agricultural College and Research Institute, Tamil Nadu Agricultural University, COIMBATORE (T. N.) INDIA

\section{Summary}

Remote sensing with hyper spectral sensors can provide the fine resolution required for sitespecific farming. The within-field spatial distribution of some soil properties was found by using multiple linear regressions to select the best combinations of wave bands, taken from among a full set of 512 narrow bands in the wavelength range of 350 to $1050 \mathrm{~nm}$. The resulting regression equations made it possible to calculate the value of the soil property with a spatial resolution of $3.0 \mathrm{~nm}$ FWHM (Full Width Half Maximum). Both surface and subsurface samples of soil profile were taken from the three research stations. The soil samples were tested in a laboratory for 20 different properties. The per cent sand was found to be detectable with a reasonable degree of accuracy with $\mathrm{R}^{2}=0.851$ for a three parameter model; the best combination of wavelengths was $426.81,730.47$ and $1037.7 \mathrm{~nm}$. For silt, clay, field capacity, wilting point, Available water content, $\mathrm{pH}$, electrical conductivity and $\mathrm{CaCO}_{3}$ the results were ranges of degree of accuracy with $\mathrm{R}^{2}$ from 0.609 to 826 . The soil exchangeable properties such as $\mathrm{Ca}$, $\mathrm{Mg}, \mathrm{Na}$ and $\mathrm{CEC}$, chemical composition such as $\mathrm{SiO}_{2}$ and $\mathrm{Fe}_{2} \mathrm{O}_{3} \mathrm{R}^{2}$ values varied from 759 to 906. The poorest fit was for organic carbon with $\mathrm{R}^{2}=0.220$ followed by $\mathrm{Al}_{2} \mathrm{O}_{3}\left(\mathrm{R}^{2}=0.313\right)$. Available micronutrients ( $\mathrm{Fe}$ and $\mathrm{Mn}$ ) had $\mathrm{R}^{2} 0.491$ and 0490. For all the properties except organic carbon and $\mathrm{Al}_{2} \mathrm{O}_{3}$, the correlation was statistically significant. The main findings were that some soil properties can be accurately detected using hyper spectral remote sensing.

Key words : Band selection, Soil profiles, Hyper spectral remote sensing, Multiple linear regression, Soil properties

How to cite this article : Malavath, Rajeshwar and Mani, S. (2017). Detection of some soil properties using hyperspectral remote sensing of semi arid region of Tamil Nadu. Asian J. Soil Sci., 12 (1) : 191-202 : DOI : 10.15740/HAS/AJSS/12.1/191-202. 